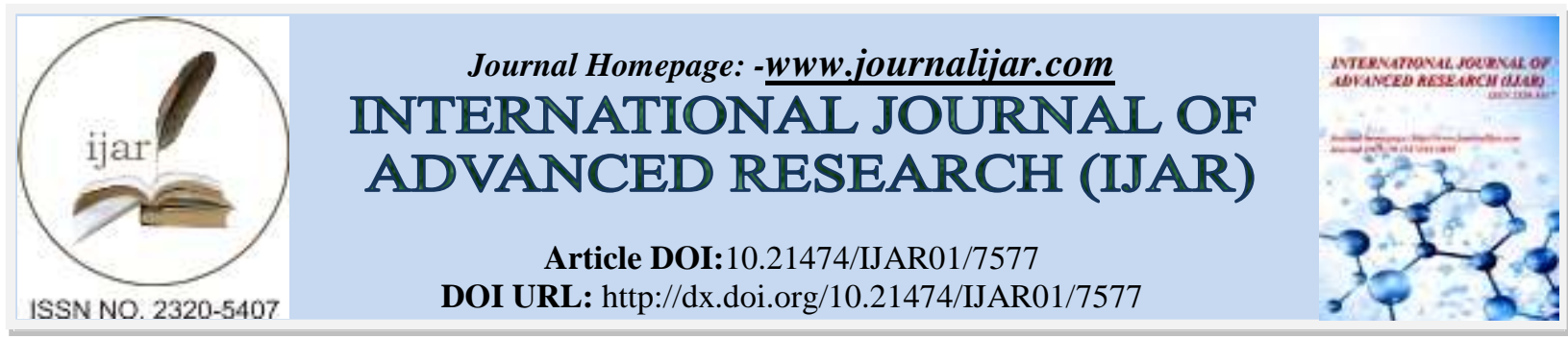

RESEARCH ARTICLE

\title{
SAFEGUARDING OF INTEGRITY IN FINANCIAL REPORTING AND PERFORMANCE OF PUBLIC TVET INSTITUTIONS IN NYANZA REGION, KENYA.
}

Oluoch Mercy Florah.

university of nairobi school of business department of business administration.

\section{Manuscript Info}

Manuscript History

Received: 16 June 2018

Final Accepted: 18 July 2018

Published: August 2018

Keywords:-

TVET Institutions, Integrity in financial reporting, Performance, Nyanza Region, KenyaIntegrity in Financial Reporting, Governance.

\begin{abstract}
Financial integrity can be broadly defined as making sure a financial report is correct, consistent, complete, andaccurate.Integrity in financial reporting, play a crucial role in overseeing financial management of the organization improving performance consequently (Mardjono, 2005; De Andres et al. 2005). The board should expect to receive from management regular financial reports comparing financial results with budgetary predictions and reporting on the status of assets.This study sought to establish the effect of safeguarding of integrity in financial reporting on performance of public TVET institutions in Nyanza region, Kenya. Although Integrity in financial reporting, play a crucial role in overseeing financial management of the organizationand improving performance,the studies on effect of safeguarding of integrity in financial reporting on performance has not been conclusive as they have revealed both positively and negatively linked results.This study used correlation research design. Population of the study included the principals, deputy principals and heads of department of TVET Institutions in Nyanza region Kenya who were 99 in number. The study employed a census survey with response at 90.9\%. Reliability was measured using cronchbach's alpha which revealed 0.872 internal consistency.The Pearson Product-Moment correlation coefficient $(\mathrm{r}=.778)$ computed indicated that there was high positive correlation between integrity of financial reporting and performance in TVET institutions from Nyanza region. The analysis revealed highly significant $(\mathrm{p}<0.05)$ positive relationship between the two variables. The regression analysis revealed a result of $\left(\beta_{3}=0.288 ; p\right.$ $=0.002$ ) which implies that integrity in financial reporting is significant. This means that integrity in financial reporting has a substantial effect on performance.Findings of this study may be used for policy formulation by policy makers to guide in appointment of the board of management to improve governance of TVET Institutions and other stakeholders for further research.
\end{abstract}

Copy Right, IJAR, 2018,. All rights reserved.

\section{Introduction:-}

To meet the board's need to evaluate the effectiveness of programs, many higher education institutions provide detailed internal statements that directly relate expenses shown on their financial statements to specific programs or 
functions. According to Roberts et al., (2005) the board should expect to receive from management regular financial reports comparing financial results with budgetary predictions and reporting on the status of assets. The board should also expect management to make financial disclosures consistent with the board's own reports to trustees, contributors and other stakeholders. This functional approach makes it easier for trustees to analyze and compare costs opinion of the public accounting firm. De Andres et al.,(2005) argue that the board should appoint a respected public accounting firm to conduct an audit of the financial records and processes of the institution. The public accounting firm is responsible for providing the board with an independent opinion. Independence both from the board and from management is an essential feature of good practice with respect to the external audit. Neither management nor trustees should attempt to influence the opinion of the public accounting firm.

According to Mardjono (2005), auditors and audit committee play a crucial role in overseeing financial management of the organization improving performance consequently. The CCG (2003) guidelines states that the board needs individuals with a strong commitment to the fundamental purpose and mission of the institution. Boards should consider performing an annual inventory of talent to assess whether the right professional capabilities are represented on the board. The board should also include individuals with the specific skills and know-how needed to examine issues through multiple lenses: legal, financial, public relations and communications, management, and professional development, among others. It is widely accepted that there exists a conventional wisdom that a higher quality level of audit forms part of a good governance mechanism.

\section{Research Objective:-}

Establish the effect of safeguarding of integrity in financial reporting on performance of public TVET institutions in Nyanza region, Kenya.

\section{Research Hypothesis:-}

$\mathrm{H}_{01}$ : Thereis noeffect of safeguarding of integrity in financial reporting on performance of public TVET institutions in Nyanza region, Kenya

\section{Empirical Review Relating Integrity Of Financial Reporting To Performance:-}

Most empirical works (Ho 2005) carried out on the relationship between audit quality and performance have revealed positive findings whilst some, like Brown and Caylor (2004) have concluded that although there is a link between audit quality, governance and financial performance, the significance of the relationship lies between audit quality and dividend yield and not with operating performance. Murya (2010) conducted a study done in the U.K on the effect of corporate governance and external audit on constraining earnings management practice. In the study, earnings management is measured using the magnitude of discretionary accruals as estimated by the performance matched discretionary accruals (Kothari et al., 2005) model. A review of the corporate governance literature reveals sixteen attributes that can impact on shareholders perception of earnings quality due to their role in enhancing financial reporting integrity. The corporate governance attributes are organized in four categories: 1) Board Composition; 2) Audit Committee Effectiveness; 3) Non-Executive Directors (NEDs) Commitment; and 4) Ownership Structures. The external audit factors include auditor independence and audit quality. Two models are constructed and a set of hypotheses are stated. These models are tested using a sample consisting of the top 350 companies listed on the London Stock Exchange. Firms in the financial, mining and regulated industries are excluded due to different accrual choices and valuation processes. The study covers the period of four financial years (2003, 2004, 2005 and 2006). Using agency theory, this study explores the effects of the corporate governance and external audit systems on helping to increase financial reporting quality and to reduce opportunistic behavior. The study computes discretionary accruals using aggregate accruals models as a method to measure earnings management. Discretionary accruals are estimated using the magnitude of discretionary accruals as estimated by the performance adjusted accruals model. The results reveal that board size and independence, audit committee independence and expertise, nomination committee independence, chairman independence, the level of NED fees and an independent and specialized external auditor are negatively associated with earnings management at significant levels.

Krisnan and Lee (2009) examined the determinants of firms' choice of the "audit committee financial experts" for a sample of Fortune 1000 firms. They tested the relationship between the demand for accounting financial experts (AFEs), potential litigation risk, and corporate governance. They found that the firms they researched do not always appoint accounting financial experts (i.e. persons with specialized accounting/ auditing experience) to their audit committees. They found that firms with higher litigation risk are more likely to have accounting financial experts 
(AFEs) on their audit committee. The association between litigation risk and the likelihood of appointing accounting financial experts occurs for firms with relatively strong governance but not for those with weak governance. Thus, their findings indicated that (1) companies with demand for accounting financial experts, measured by potential litigation risk, seem to be able to secure accounting financial experts, but (2) such benefits only accrue in the presence of otherwise strong corporate governance (Krishnan \& Lee 2009).

Farouk et al., (2014) report a research study designed to examine the impact of audit quality on financial performance of quoted firms in Nigeria. The study is descriptive in nature and the correlational and ex-post facto designs were adopted in carrying out this research. Data were obtained basically from the published annual reports and accounts, and notes to the financial statements of the four firms that represent the sample of the study. The data collected were quantified and presented in tables. Multiple regression analysis using the SPSS Version 15.0was employed in analyzing the data and testing the stated hypotheses. The descriptive statistics for each of the variables were determined to show the minimum, maximum, mean and standard deviation values. Descriptive statistics is used in the study to help readers to understand the measures of central tendency and measures of variances associated with the variables of the study. The results of the findings show that the impact of audit quality on financial performance is positive and significant. The results reveal that "the greater the degree of an auditors independence, the greater the propensity of a firm making substantial net profit margins" The impact of auditor size is also positive and significant, although, its impact is lesser than that of auditor independence. A positive relationship between auditor independence and financial performance implies that audit effort increases with the amount of audit fees paid and leads to more commitment and monitoring on the part of the of the auditors, thereby decreasing the propensity of an organization to incur losses through non-adherence to accounting principles and unnecessary waste of funds by management. Audit fees do not compromise auditor independence, which normally would be thought to decrease an auditor's willingness to oppose management attempts to take advantage of this information asymmetries in the principal agent relationship. On the contrary, the results imply that auditors' fees give auditors a sense of responsibility and the desire to ensure that the organization gets value for money by giving the firm the best audit service possible. The impact of auditor size is reported as an important factor for determining audit quality.

Ettredgeet al., (2008) investigated client choice of industry auditors from among the Big 4 or 5 in an international setting. They investigated client-specific industry level and country-level factors. They found that international choice of home based Big 4 or 5 specialist auditors is positively associated with audit quality, capital intensity and membership in a regulated industry. Bouaziz (2012) examined the relationship between auditor size and financial performance on a sample of 26 Tunisian firms listed on the Tunis Stock Exchange. The result shows that auditor size has an important impact on the financial performance of firms in terms of return on assets and return on equity.

Miettinen (2011) examined the relationship between audit quality and financial performance. Audit quality was measured using auditor size and audit committee meeting frequency. The result shows that audit quality has both a direct effect as well as a mediated effect through audit size on financial performance. The results imply that measures of audit quality are not merely symbolic but that they contribute to financial performance.

Anderson and Verma (2012) examined the relationship between auditor size, auditor tenure and audit firm rotation using a probit model which they developed. The data they collected from 2,148 listed Asian companies shows that big audit firms provide high quality audit because big audit firms are more conservative than non-big audit firms. They also discovered that national level factors have a strong influence on audit quality. Auditor tenure is associated with impaired audit quality and audit firm rotation can help promote audit quality.

Basedon issues raised in this paragraph, the literature recognizes that members of audit committees need to possess certain professional and personal attributes and qualities in order to perform their role through functional activities, processes, procedures. However, this research seeks to determine the influence of integrity of financial reporting on performance. The empirical studies, report that there is a link between audit quality and financial performance. It is noted that much of the published material on integrity of financial reporting is on effectiveness of audit committees and on top of this the reviewed studies were done on accounting firms. The almost total absence of an empirical investigation on the relationship of integrity of financial reporting and performance, justifies this research. 


\section{Research Methodology:- \\ Research Design}

This study adopted a correlation design. The design was expected to test the hypotheses and meet objectives of the study. Correlational approach helped determine whether and to what degree a relationship exists between quantifiable variables (Mugenda and Mugenda, 2008)

\section{Data Analysis:-}

\section{Results and Discussion:-}

The effect of safeguarding of integrity in financial reporting on performance of public TVET institutions. The effect of safeguarding of integrity in financial reporting on performance was assessed using the coefficient of determination $\mathrm{r}^{2}$. The coefficient of determination was used to assess the proportion of variation of the dependent variable on independent variable. Basically it is worked out from a square of the Pearson correlation between the variables.

Coeffiecient of determinatin $\left(\mathrm{r}^{2}\right)=(\text { Pearson Correlation coefficient })^{2}$.

Findings on the Effect of Safeguarding of Integrity in Financial Reporting on Performance of Public TVET Institutions in Nyanza Region, Kenya.

This objective of the study was investigated by the use of a questionnaire designed to seek the respondents' views on the constructs of integrity in financial reporting. The key aspect of integrity in financial reporting include, departmental audit, independence of audit, regular report reviews, competency of personnel in accounts and finance departments, adequacy of financial management system, and preparation and planning of board meetings. True to the generally held opinion that there is a link between audit quality and financial performance, the findings of the study, as reflected in Table 4.11, show that TVET institutions recognize this fact has adopted to safeguard sound financial reporting.

Frequency of response on safeguarding of integrity in financial reporting Frequency percentages of response on integrity in financial reporting

\begin{tabular}{|l|l|l|l|l|l|}
\hline & $\begin{array}{l}\text { Strongly } \\
\text { Agree }\end{array}$ & Agree & Undecided & Disagree & $\begin{array}{l}\text { Strongly } \\
\text { Disagree }\end{array}$ \\
\hline Departmental audit & 5.6 & 44.4 & 12.2 & 28.9 & 8.9 \\
\hline Independent audit & 5.6 & 44.4 & 11.1 & 28.9 & 10.9 \\
\hline Regular report review & 12.2 & 40.0 & 14.4 & 32.2 & 1.1 \\
\hline Competent personnel & 13.3 & 52.2 & 12.2 & 17.8 & 4.4 \\
\hline Adequate financial management system & 17.8 & 46.7 & 8.9 & 17.8 & 8.9 \\
\hline Satisfactory board meetings & 11.1 & 57.8 & 14.4 & 12.2 & 4.4 \\
\hline
\end{tabular}

Source: Survey Data (2015)

The findings of the study show that there were some elements of departmental audit within the various TVET institutions that the study focused on. The analysis of the responses indicate that majority (51\%) of the respondents expressed an agreement with the assertion that departmental audit were being undertaken regularly. Those who were undecided were $12.2 \%$ whereas those who were in disagreement were $37.8 \%$. This revealed that despite the fact that majority of the respondents agreed that auditing was done in all departments in the institution, a significant proportion of them did not accept that fact. On the same note, there was evident of divided opinion on whether there was independence in audit. Although 50\% of the respondents were in agreement that independent audit was being done within their institutions, $38.9 \%$ of them denied the allegation that audit was conducted by independent auditors and $11.1 \%$ decided not to divulge their view on the matter.

On the competency of the personnel in the financial department, the findings indicate that $52.2 \%$ of the respondents agreed that the institutions had competent personnel and $13.3 \%$ of the respondents strongly agreed to this statement. Those who agreed argued that the directors ensured that qualified and competent personnel were employed to undertake accounting and financial responsibility. Whereas $12.2 \%$ of the respondents were undecided, those who generally disagreed were $22.2 \%$ of the respondents. When the respondents views was sought on adequacy of financial management system, the findings of the study indicate that nearly two thirds $(64.4 \%)$ of the respondents agreed that the financial information management system was adequate. They held the view that the directors 
maintain adequate systems of financial management control over the institutions. The number of the respondents who accepted that financial system was adequate was overwhelmingly over and above those who disagreed (26.7\%) that adequacy of financial management system existed. However, there were satisfactory board meetings in most TVET institutions as indicated by the over two thirds (68.9\%) of the respondents who were in agreement that there were acceptable board meetings within the institutions. It was established that the board of directors regularly review reports from the executive committee, audit committee, other committees of the board, compliance personnel, and outside experts at board meetings. On the flip flop, $16.6 \%$ of respondents disagreed that there were satisfactory board meetings and another $14.4 \%$ of the remained undecided on the matter. Those who disagreed argued that preparation and planning of board meetings were not satisfactory.

Descriptive Statistics of Responses on safeguarding of Integrity in Financial Reporting

Table 1:-Descriptive Statistics Of Responses On Integrity In Financial Reporting

\begin{tabular}{|l|l|l|l|l|}
\hline \multicolumn{4}{|l|}{} \\
\cline { 2 - 5 } & $\mathrm{N}$ & Mean & Std. Deviation \\
\cline { 2 - 5 } & Statistic & Statistic & Std. Error & Statistic \\
\hline Departmental audit & 90 & 2.91 & .121 & 1.148 \\
\hline Independent audit & 90 & 2.93 & .123 & 1.169 \\
\hline Regular report review & 90 & 2.70 & .114 & 1.086 \\
\hline Competent personnel & 90 & 2.48 & .113 & 1.073 \\
\hline Adequate financial system & 90 & 2.53 & .130 & 1.229 \\
\hline Satisfactory board meetings & 90 & 2.41 & .105 & .993 \\
\hline
\end{tabular}

Source: Survey Data (2015)

Table 4.12 shows that most respondents had comparatively more confidence with independence of the auditing department as an element of integrity of financial reporting. This was indicated by the highest mean $(\mathrm{M}=2.93$, Std.Dev. $=1.169$ and Std.Error =.123). Preparation and planning of the board meetings had the poorest performance, with the mean of 2.41, standard deviation of .993 and standard error of .105.

\section{Hypothesis Testing}

To address this objective of the study, the null hypothesis "there is no relationship between timely and integrity of financial reporting and performance of TVET institutions in Nyanza region, Kenya" was tested. To do this a correlation analysis was conducted. The set of scores on the integrity of financial reporting was used as the independent variable while scores from performance of TVET questionnaire was used as the explanatory variable (dependant variable).

Table 1.1:-Correlations of Performance

\begin{tabular}{|l|l|l|l|}
\hline \multicolumn{2}{|c|}{} \\
\hline \multirow{3}{*}{ Performance } & Performance & $\begin{array}{l}\text { Integrity of financial } \\
\text { reporting }\end{array}$ \\
\cline { 2 - 4 } & Pearson Correlation & 1 & $.778^{* * *}$ \\
\cline { 2 - 4 } & Sig. (2-tailed) & & .000 \\
\cline { 2 - 4 } Integrity of financial reporting & $\mathrm{N}$ & 90 & 90 \\
\cline { 2 - 4 } & Pearson Correlation & $.778^{* *}$ & 1 \\
\cline { 2 - 4 } & Sig. (2-tailed) & .000 & 90 \\
\cline { 2 - 3 } & $\mathrm{N}$ & 90 & \\
\hline
\end{tabular}

Correlation is significant at the 0.01 level (2-tailed). Source: Survey Data (2015)

The Pearson Product-Moment correlation coefficient $(\mathrm{r}=.778)$ computed indicated that there was high positive correlation between integrity of financial reporting and performance in TVET institutions from Nyanza region. The analysis revealed highly significant $(\mathrm{p}<0.05)$ positive relationship between the two variables. (SSPS output is shown in Table 4.12).Hence it is acceptable to conclude that there was a significant positive association between integrity of financial reporting and performance of TVET institutions. The coefficient of determination $\mathrm{R}^{2}=60.52 \%$, implied that influence of integrity of financial reporting alone help to account for $\approx 61$ per cent of the variance in respondents' scores on the performance scale in the questionnaire of the respondents. This finding is in line with 
(Krishnan and Lee 2009).Farouk et al., (2014);Bai et al., (2008) who explain how false financial statements, no matter if it is there by manipulation or error, will affect the whole report. Overstating revenue would mutually increase account receivables and/or cash, as well as the other way around. This higher income will raise the shareholders equity since shareholders equity is mostly based on income. If the companies on the other hand choose to underestimate expenses it would jointly raise cash or inventoryaccounts, this would lead to overstated total assets.

\section{References:-}

1. Anderson, A. (2009). Independent Governance: Risk and Assurance,Consultants report for the OECD

2. Bouaziz, Z. (2012).The Impact of the Presence of Audit Committees onthe Financial Performance of Tunisia Companies. International Journal of Management \& Business Studies, 3:717-735.

3. Brown, L., and Caylor, M. (2006). Corporate governance and firm operating Performance.Georgia State University.Journal of Accounting and Public Policy 25: 409-434.

4. De Andres, P. A., Azofra, V. and Lopez, F. (2005). Corporate boards in some OECD countries: Size, composition, functioning and effectiveness, CorporateGovernance. An International Review, 13, 197-210.

5. Ettredge, M. J., Heintz, C. L. andScholz, S.(2008). Auditor realignments accompanying implementation of SOX 404 reporting requirements. Working paper, University of Kansas.

6. Farouk, M. A., and Hassan, S.U. (2014). Impact of Audit Quality and Financial Performance of Quoted Cement Firms in Nigeria.International Journal of Accounting and Taxation, 2,2372-4978

7. Ho, Chi-Kun (2005). Corporate Governance and corporate competiveness: An International Analysis, Vol. 13, Issue 2 page $211-253$

8. Kothari, S. A., Leone, andWasley, C. (2005). Performance matched discretionary accrual measures.Journal of Accounting and Economics39: 163-197.

9. Krishnan, J \& Lee, J.E. (2009) Audit Committee Financial Expertise, Litigation Risk, and Corporate Governance. A Journal of Practice \& Theory: May 2009, Vol. 28, No. 1, pp. 241-261.

10. Mardjono A. (2005). "A tale of Corporate Governance: lessons why firms fail", Managerial Auditing Journal, Vol. 20, No 3, pp: 272-383.

11. Miettinen, J. (2011). The role of audit quality on the relationship between auditee'sagency problems and financial information quality. Paper presented at the Department of Accounting and Finance, University of Vaasa, Finland.

12. Murya, H. (2010).'The Effectiveness of Corporate Governance and External Audit on Constraining Earnings Management Practice in the UK. Durham: Durham University.

13. Roberts, J., McNulty, T. and Stiles, P. (2005). 'Beyond Agency Conceptions of the Work of the Non-Executive Director: Creating Accountability in the Boardroom', British Journal of Management, 16: 1-22. 